\title{
Perbandingan Kinerja Perusahaan Dengan Pendekatan Balanced Scorecard Pada BPR Syariah
}

\begin{abstract}
ANGRUM PRATIWI
Fakultas Agama Islam, Universitas Muhammadiyah Sumatera Barat E_mail: mahyudinritonga@gmail.com
\end{abstract}

\section{ABSTRACT}

This research aims to discover the progress of BPRS in Yogyakarta by using balanced scorecard (BSC) approach. BSC is a concept of management that help to translate the company strategy into company activities. There are four aspects to be evaluated in the BSC: financial prospective, consumen, internal business, growth and learning. This research is a descriptive and comparative research. The author conducted fieldwork in two BPRS, which are BPRS Barokah Dana Sejahtera and BPRS Bangun Drajat Warga. The research sampel comprises financial aspect (financial report of 2012-2014); consumen aspect (400 respondents); growth and learning (69 respondents); and internal bussiness aspect (questioner and interview). There is not much difference between the two BPRS in their financial, consumen, growth and learning, and internal bussiness aspects. Yet, there is differences between the two in their NPF, KPMM, FDR, finance, profit-sharing, and DPK. In a nutshel, the research result shows that BPRS Barokah is greater in its growth thaks to a solid team work.

\section{ABSTRAK}

Penelitian ini bertujuan mengetahui perbedaan kinerja Bank Pembiayaan Rakyat Syariah yang ada di Yogyakarta dengan pendekatan balanced scorecard (BSC). BSC sendiri merupakan konsep manajemen yang membantu menerjemahkan strategi perusahaan dalam suatu tindakan nyata yang diturunkan dari visi dan misi perusahaan. Terdapat empat prespektif yang dinilai dalam BSC, yaitu prospektif keuangan, konsumen, bisnis internal, pertumbuhan serta pembelajaran. Jenis penelitian yang digunakan adalah penelitian deskriptif dengan desain penelitian komparatif. Penulis melakukan penelitian langsung ke lapangan pada dua objek penelitian yaitu BPRS Barokah Dana Sejahtera dan BPRS Bangun Drajat Warga. Sampel penelitian pada perspektif keuangan yaitu laporan keuangan per-kuartal 
periode 2012-2014. Pada prespektif konsumen kedua BPRS berjumlah 400 responden dan prespektif pembelajaran serta pertumbuhan berjumlah 69 responden. Sedangkan, prespektif bisnis internal berupa kuyesioner dan wawancara. Hasil uji beda menunjukkan bahwa kinerja perspektif konsumen, perspektif bisnis internal, serta perspektif pembelajaran dan pertumbuhan BPRS Barokah Dana Sejahtera dan BPRS Bangun Drajat Warga tidak mempunyai perbedaan. Namun, hasil uji beda prespektif keuangan menunjukkan perbedaan pada NPF, KPMM, FDR, kas, pembiayaan, bagi hasil, kewajiban segera dan DPK. Meskipun demikian, hasil kuesioner menunjukkan BPRS Barokah Dana Sejahtera terlihat lebih unggul pada prespektif pertumbuhan dan pembelajaran karena adanya team work yang solid.

Kata kunci : Kinerja Perusahaan, Balanced Scorecard dan BPRS

\section{PENDAHULUAN}

Keruntuhan pasar keuangan tahun 2008 memicu munculnya istilah "credit cruch" dan memiliki dampak yang merusak industri jasa keuangan. Masih hangat dalam ingatan kita bahwa krisis 2008 meruntuhkan pasar keuangan di Amerika seperti Lehman Brothers, Merrill Lynch, dan Royal Bank of Scotland di Inggris yang hanya bisa bertahan dengan bantuan dari Bank Sentral. Para ahli ekonom dan ahli lainnya khawatir bahwa credit cruch akan membawa dunia memasuki resesi yang mungkin sama dengan Depresi Besar seperti pada tahun 1930-an, yang dipicu oleh krisi kepercayaan terhadap industri perbankan. Oleh karena itu, tidaklah mengherankan bahwa menjaga kesetian konsumen menjadi kekhawatiran tersendiri bagi sebagian besar industri keuangan ${ }^{1}$.

Metode yang digunakan jasa keuangan untuk menjaga kesetian konsumen salah satunya dengan balanced scorecard (BSC). Dimana, perusahaan jasa keuangan akan lebih mampu dalam meramalkan dan merencakan perbaikan terhadap kesetian dan mempertahankan konsumen. Praktek BSC diperkenalkan pertama kali oleh Scotiabank Kanada pada tahun 2001. Pada tahun 2009 setelah credit cruch terjadi, Scotiabank Kanada tetap mampu meraih keberhasilan karena BSC tidak saja melihat kinerja keuangan, namun bagaimana memenuhi tujuan konsumen dengan kinerja secara "seimbang" diseluruh aspek ${ }^{2}$.

Latar belakang penciptaan ide balanced scorecard (BSC) dicetuskan oleh Dr. David P. Norton dan Dr. Robert S. Kaplan yang dilunculkan dalam artikel Harvard Business Review pada tahun 1992. Ide tersebut muncul dari argumen sederhana, bahwa model keuangan saja tidak lagi mencukupi untuk mengelola perusahaan. Workshop tentang BSC pertama kali diperkenalkan pada kuartal 
ke empat tahun 1993 kepada para pemimpin bisnis dengan menciptakan serangkaian strategi yang digolongkan ke dalam empat prespektif yaitu keuangan, eksternal, internal, serta pembelajaran dan pertumbuhan. Harvard Business Review mengatakan bahwa ide manajemen BSC ini memiliki dampak tersbesar terhadap bisnis selama 75 tahun terakhir pada abad ke-20 dan berlangsung hingga saat ini dengan banyak workshop dan penelitian yang dilakukan³.

Di Asi-Pasifik sendiri menurut studi yang dilakukan oleh Bain \& Company tahun 2007, merupakan wilayah dengan pemakai balanced scorecard paling cepat. Khusus untuk wilayah Indonesia, meskipun tidak mengalami restrukturisai industri perbankan dari dampak credit cruch tahun 2008 silam. Indonesia rupanya sudah melakukan tranformasi industri perbankan sejak krisi tahun 1997 dengan mempelajari berbagai strategi untuk recovery ekonomi seperti corporate governance dan balanced scorecard. Untuk penerapan balanced scorecard, Bank CIMB Niaga Indonesia telah mengadopsi metode ini sejak tahun 2008 pada tingkat korporasi, direktur, dan karyawan sebagai upaya pertumbuhan dimasa mendatang. Studi lain pada Bank Indonesia yang telah menerapkan balanced scorecard dari tingkat korporasi hingga ke tingkat karyawan individu4.

Menghadapi Masyarakat Ekonomi ASEAN (MEA) akhir tahun 2015 ini, perbankan perlu memfokuskan strategi perencanaan, pengorganisasian, pengoperasian, dan pengendalian sehingga siap bersaing di tingkat global. Karena, para konsumen saat ini diberikan kebebasan memilih bank mana yang mampu memberikan pelayanan memuaskan dan professional, sehingga strategi dan kinerja perusahaan pun harus berorientasi pada keinginan nasabah tersebut. Pengukuran kinerja dari aspek keuangan merupakan kinerja tradisional dan kurang tepat jika diterapkan perbankan saat ini, karena tujuan utama perusahaan perbankan adalah memberikan layanan jasa yang sebaik-baiknya kepada masyarakat ${ }^{5}$. Untuk itu dunia perbankan perlu metode kinerja yang seimbang dengan menggunakan balanced scorecard. Kelebihan dari balanced scorecard adalah konsep ini mampu menginterpretasikan visi dan misi perusahaan kedalam empat perspektif yang akan menjadi tolak ukur pengukuran kinerja yang ada 6 .

Kinerja industri perbankan Indonesai pasca krisis global tahun 2008, tetap cukup solid dengan rasio kredit/pembiayaan, likuiditas dan pasar yang cukup terjaga. Stabilitas sistem keuangan didukung oleh kinerja perbankan yang positif baik dari sisi fungsi intermediasi perbankan maupun efisiensi termasuk 
didalamnya industri perbankan syariah7. Halim Alamsyah (2012), menyatakan bahwa industri perbankan syariah mampu menunjukkan akselerasi pertumbuhan yang tinggi rata-rata sebesar 40,20\% pertahun dalam lima tahun terakhir (2007-2011), sementara rata-rata pertumbuhan perbankan nasional hanya sebesar $16,7 \%$ pertahun. Oleh karena itu, industri perbankan syariah dijuluki sebagai "the fastest growing industry". Akselerasi pertumbuhan perbankan syariah yang jauh lebih tinggi dari pertumbuhan perbankan nasional berhasil meningkatkan porsi perbankan syariah dalam perbankan nasional menjadi 4,0\%. Jika tren tersebut dapat dipertahankan, maka porsi perbankan syariah diperkirakan dapat mencapai 15\%-20\% dalam kurun waktu sepuluh tahun ke depan ${ }^{8}$.

Salah satu instrumen yang turut membantu tumbuh kembangnya industri perbankan di Indonesia yaitu dengan adanya Bank Pembiayaan Rakyat Syariah (BPRS) yang turut mendorong perkembangan sektor riil. Dalam rangka penguatan struktur perbankan untuk mendukung pengembangan dan transformasi ekonomi nasional dimasa mendatang, Bank Indonesia menetapkan beberapa arah kebijakan, salah satunya mendorong peningkatan alokasi pembiayaan produktif dan UMKM dan perluasan jaringan ke berbagai daerah ${ }^{9}$. Untuk itu perlu adanya dorongan serta evaluasi kepada industri BPRS agar terus tumbuh perkembang dan meningkatkan kinerja dalam persaingan nasional dan global.

Adapun pembentukan Daerah Istimewa Yogyakarta (DIY) bertumpu pada keberadaan Kraton Ngayogyakarta Hadiningrat yang secara spesifik membangun 'image' Kota Yogyakarta sebagai Kota Budaya, Kota Perjuangan, Kota Pendidikan dan Kota pariwisata. Hal ini terbentuk atas berkembangnya fungsi-fungsi pelayanan kota yang dominan sejalan dengan tumbuh dan berkembangnya pembangunan masyarakat ${ }^{10}$. Berkaitan dengan perkembangan perbankan di wilayah DIY, berdasarkan hasil laporan Bank Indonesia pada akhir tahun 2013 kinerja perbankan DIY menunjukkan perlambatan. Hal ini terlihat dari aset perbankan DIY tumbuh 15,88\% yang lebih rendah dibandingkan periode yang sama pada tahun sebelumnya yang tumbuh $20,12 \%$. Perkembangan perbankan DIY pada akhir tahun 2014 menunjukkan hal yang sama, adanya perlambatan pada indikator kinerja utama yaitu aset yang tumbuh sebesar 13,67\% lebih rendah dibanding triwulan sebelumnya yang mampu tumbuh sebesar 14,27\% dan lebih rendah dari pertumbuhan akhir tahun 2013. Meskipun demikian, perkembangan perbankan syariah DIY pada Desember 2013 justru menunjukkan pertumbuhan yang lebih baik. Aset tercatat 
tumbuh lebih tinggi dibandingkan triwulan yang sama pada tahun sebelumnya. Hal yang sama terjadi pada Desember 2014, dimana perkembangan usaha perbankan syariah masih terus mengalami peningkatan pada aset dan dana pihak ketiga ${ }^{11}$.

Pertumbuhan perbankan syariah nasional tentunya tak lepas dari peran dan kontribusi lembaga keuangan syariah di wilayahnya masing-masing. Dalam hal ini tentunya DIY turut andil dalam pertumbuhan perbankan nasional. Perkembangan perbankan syariah di Yogyakarta dapat kita lihat pada Tabel 1.1, dimana Bank Umum Syariah (BUS) masih mendominasi total aset serta pembiayaan dibanding dengan Bank Pembiayaan Rakyat Syariah (BPRS). Jumlah BUS yaitu enam bank, sedangkan jumlah BPRS sebanyak 11 unit yang tersebar di Kota Yogyakarta, Kab. Sleman dan Kab. Bantul. Dalam kegiatan penyaluran dana, BPRS lebih agresif yang terlihat pada rasio FDR, hampir sebagian besar aset yang dimiliki dialokasikan pada pembiayaan. Namun, BPRS tidak mampu menjaga rasio NPF dengan baik dan terlihat semakin meningkat pada kuartal kedua 2014 menjadi 8.97\%. Tentunya ini menjadi perhatian penting bagi para pengelola BPRS DIY untuk mengelola risiko pembiayaan dengan lebih intensif agar tidak berdampak negatif bagi pertumbuhan perbankan syariah regional DIY.

Tabel 1.1 Kinerja Perbankan Syariah Daerah Istimewa Yogyakarta

\begin{tabular}{llllllllll} 
ASET (Miliar Rp) & 2008 & 2009 & 2010 & 2011 & 2012 & 2013 & Q I-2014 & Q II-2014 & Q III-2014 \\
\hline BUS & 800 & 1,194 & 1,643 & 2,196 & 2,634 & 3,416 & 4,665 & 3,550 & 3,779 \\
BPRS & 56 & 93 & 127 & 168 & 242 & 267 & 274 & 274 & 292 \\
PEMBIAYAAN (M Rp) & 2008 & 2009 & 2010 & 2011 & 2012 & 2013 & Q I-2014 & Q II-2014 & Q III-2014 \\
\hline BUS & 511 & 627 & 862 & 1,386 & 1,639 & 1,997 & 2,010 & 2,307 & 2,442 \\
BPRS & 49 & 73 & 106 & 151 & 199 & 233 & 243 & 263 & 300 \\
RASIO FDR (\%) & 2008 & 2009 & 2010 & 2011 & 2012 & 2013 & Q I-2014 & Q II-2014 & Q III-2014 \\
\hline BUS & 87.81 & 76.17 & 70.09 & 83.01 & 72.60 & 69.74 & 68.53 & 75.67 & 76.41 \\
BPRS & 119.09 & 116.16 & 113.46 & 122.03 & 105.72 & 109.60 & 113.09 & 122.53 & 131.63 \\
RASIO NPF (\%) & 2008 & 2009 & 2010 & 2011 & 2012 & 2013 & Q I-2014 & Q II-2014 & Q III-2014 \\
\hline BUS & 1.39 & 1.56 & 3.77 & 1.84 & 1.13 & 1.25 & 1.60 & 1.80 & - \\
BPRS & 9.11 & 6.31 & 5.56 & 4.89 & 4.95 & 5.24 & 6.53 & 8.97 & 8.05 \\
\hline \multicolumn{5}{c}{ Sumber: Laporan Perkembangan Perekonomian DIY, Tahun 2010, $2012 \&$ Kuartal ke-III 2014}
\end{tabular}

Berdasarkan berbagai isu terkait pentingnya penerapan balance scorecard (BSC) pada industri perbankan, semakin pesatnya pertumbuhan BPRS di DIY. Peneliti tertarik untuk melakukan sebuah penelitian bagaimana penerapan BSC sebagai salah satu penilaian kinerja yang "berimbang" pada BPRS. Mengingatkan belum adanya penilaian baku secara menyeluruh, seperti yang telah diterapkan pada Bank Umum/Bank Umum Syariah melalui laporan Good 
Corporate Governance (GCG). Bank Indonesia telah mengeluarkan peraturan resmi sejak tahun 2006, melalui Peraturan Bank Indonesia (PBI) No. 8/4/PBI/ 2006 tanggal 30 Januari 2006 tentang Penerapan GCG bagi Bank Umum. Untuk itu BSC bisa dijadikan salah satu penilaian kinerja BPRS secara berimbang dari semua aspek kinerja.

Penulis melakukan penelitian pada perusahaan yang bergerak di bidang jasa keuangan syariah di Yogyakarta. Dari sebelas BPRS yang tersebar di Kota Yogyakarta, Kabupaten Sleman, dan Kabupaten Bantul, hanya dua BPRS yaitu BPRS Barokah Dana Sejahtera dan BPRS Bangun Drajat Warga yang memenuhi kriteria dan bersedia untuk penulis teliti. Kriteria pengambilan objek terkait dengan kinerja keuangan yaitu total aset kedua BPRS telah mencapai angka lebih dari Rp 50 miliyar hingga Desember 2014, pencapaian pada laba bersih dan penghargaan kinerja keuangan yang dicapai keduanya dari majalah InfoBank dengan predikat "Sangat Bagus" tahun 2013 dan 2014. Kriteria lainnya yaitu kedua BPRS telah memiliki kantor cabang/kas lebih banyak dari BPRS yang sekelas di kota Yogyakarta, hal ini memungkin peneliti memperoleh data serta informasi yang lebih luas guna mendukung penelitian. Untuk itu peneliti mencoba melakukan penilaian kinerja dengan pendekatan balanced scorecard, kemudian membandingkan kinerja kedua BPRS tersebut. Dengan adanya penelitian kinerja BPRS dengan menggunakan metode balanced scorecard penulis berharap mampu memberikan masukan, saran serta kontribusi untuk kemajuan dan meningkatkan kinerja BPRS di wilayah Yogyakarta.

Berdasarkan uraian di atas, permasalahan yang dapat dirumuskan dalam penelitian ini adalah:

1. Bagaimana kinerja perusahaan PT. BPR Syariah Barokah Dana Sejahtera dengan pendekatan balanced scorecard?

2. Bagaimana kinerja perusahaan PT. BPR Syariah Bangun Drajat Warga dengan pendekatan balanced scorecard?

3. Adakah perbedaan kinerja kedua Bank Pembiayaan Rakyat Syariah tersebut dengan pendekatan balanced scorecard?

\section{LANDASAN TEORI}

\section{Kinerja Perusahaan}

Kinerja perusahaan adalah suatu tampilan keadaan secara utuh atas perusahaan selama periode waktu tertentu, merupakan hasil atau prestasi 
yang dipengaruhi oleh kegiatan operasional perusahaan dalam memanfaatkan sumber daya yang dimiliki. Kinerja pada dasarnya merupakan sesuatu yang dihasilkan atau hasil kerja yang dicapai dari suatu usaha. Sedangkan, pengertian kinerja perusahaan merupakan sesuatu yang dihasilkan oleh organisasi dalam periode tertentu dengan mengacu kepada standar yang telah ditetapkan. Dari penjelasan tersebut dapat disimpulkan pengertian kinerja keuangan adalah kemampuan kerja manajemen keuangan dalam mencapai prestasi kinerjanya ${ }^{12}$. Tujuan pokok penilaian kinerja adalah untuk memotivasi personel dalam mencapai sasaran organisasi dan dalam mematuhi standar perilaku yang telah ditetapkan sebelumnya, agar membuahkan tindakan dan hasil yang diinginkan oleh organisasi ${ }^{13}$.

\section{Manajemen Strategik}

Manajemen strategik adalah suatu proses yang digunakan oleh manajer dan karyawan untuk merumuskan dan mengimplementasikan strategi dalam penyediaan costumer value terbaik guna mewujudkan visi perusahaan. Strategi adalah pola atau tindakan utama yang dipilih untuk mewujudkan visi perusahaan melalui misinya. Dari penjelasan tersebut terdapat empat hal penting mengenai manajemen strategik, yaitu manajemen strategik merupakan suatu proses yang melibatkan banyak orang dalam organisi, proses digunakan untuk merumuskan dan mengimplementasikan strategi, strategi digunakan untuk menyediakan consumer value terbaik guna mewujudkan visi perusahaan, dan terakhir manajer serta karyawan adalah pelaku manajemen strategik ${ }^{14}$. Adapun sistem manajemen strategik yang berbasis balanced scorecard (BSC) adalah manajemen strategik yang dilaksanakan secara bersistem dan memanfaatkan BSC sebagai kerangka dalam sistem perencanaan strategik.

Balanced Scorecard menjadi inti sistem manajemen strategik, karena memiliki peran dalam memperluas setiap tahap dalam manajemen strategik. Sebagai akibat penggunaan kerangka BSC dalam sistem perencanaan strategik ini, maka semua sistem sesudahnya dipengaruhi secara signifikan oleh kerangka BSC dimana lima tahap lainnya dalam manajemen strategik juga dipengaruhi.

\section{Konsep Balanced Scorecard}

BSC merupakan suatu konsep manajemen yang membantu menerjemahkan strategi perusahaan dalam suatu tindakan yang diturunkan dari visi dan misi yang ingin dicapai perusahaan. Dengan demikian BSC merupakan suatu sistem 
pengukuran kinerja manajemen atau sistem manajemen strategis yang diturunkan dari visi dan misi yang diwujudkan secara nyata dalam suatu bisnis ${ }^{15}$.

BSC merupakan suatu sistem manajemen, pengukuran dan pengendalian yang secara cepat, tepat dan komprehensif dapat memberikan pemahaman kepada manajer tentang performance bisnis. Pengukuran kinerja tersebut memandang unit bisnis dari empat perspektif, yaitu perspektif keuangan, perspektif konsumen, proses bisnis internal serta proses pembelajaran dan pertumbuhan ${ }^{16}$. Keunggulan pendekatan BSC mampu menghasilkan rencana strategik yang memiliki karakter sebagai berikut ${ }^{17}$ :

a. BSC menciptakan strategi yang komprehensif, koheren, terukur dan berimbang,

b. BSC menghasilkan company scorecard sebagai titik awal proses cascading.

c. BSC menghasilkan Open Book Management dan Perencanan Strategik.

Terdapat empat perspektif yang dikembangkan dalam BSC, empat prespektif tersebut yaitu:

1) Prespektif Keuangan

Dalam konsep BSC kinerja keuangan harus dilihat dari dua sudut pandang yaitu tujuan jangka pendek dan tujuan jangka panjang. Dalam tujuan jangka pendek, strategi yang digunakan adalah strategi peningkatan produktivitas seperti perbaikan struktur biaya dan pemaksimalan utilitas aset. Tujuan jangka panjang dilakukan strategi khusus yang disebut dengan strategi pertumbuhan. Strategi ini meliputi dua hal utama yaitu peningkatan pendapatan dan peningkatan nilai bagi konsumen ${ }^{18}$.

2) Prespektif Konsumen

Prespektif konsumen dalam BSC memiliki dua kelompok pengukuran, yaitu ${ }^{19}$ : Customer core measurement memiliki beberapa komponen pengukuran, yaitu: market share, customer retention, customer acquisition, customer satisfaction, dan customer profitabilty.

Kedua yaitu Customer Value Proposition, dalam konsep balanced scorecard, perusahaan harus bisa menciptakan customer value. Customer value adalah selisih antara manfaat yang diperoleh customer dari produk/jasa yang dikonsumsinya dengan pengorbanan yang dilakukan customer untuk mendapatkan manfaat tersebut. Customer value proposition merupakan pemicu kinerja yang terdapat dalam core value proposition yang didasarkan pada atribut sebagai berikut ${ }^{20}$ :

a) Product/Service Attributes, terdiri dari beberapa komponen yaitu price, 
quality, availability, selection dan fuctionality.

b) Relationship, terdiri dari dua komponen penting yaitu service (pelayanan kepada konsumen) dan partnership (hubungan perusahaan dengan konsumen).

c) Image (reputasi), adanya image atau reputasi yang dibangun perusahaan agar konsumen tertarik kerjasama dengan menjaga kualitas yang menjanjikan.

3) Proses Bisnis Internal

Proses bisnis internal dibagi ke dalam tiga komponen: innovation (inovasi), operations (opersi), post-sale service (layanan purna jual) (Lihat Gambar 2.1).

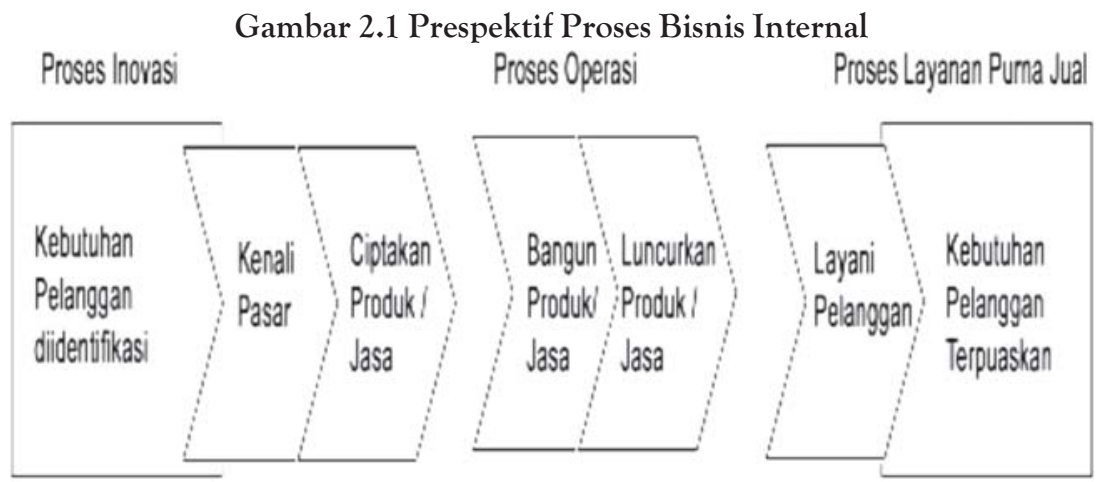

Sumber: Sony Yuwono., dkk, 2004: 41. (Diadaptasi dari Robert S. Kaplan \& Davis P. Norton, 1996: 63)

4) Prespektif Pembelajaran \& Pertumbuhan

Prespektif pembelajaran serta pertumbuhan dalam balanced scorecard erat kaitannya dengan sumber daya yang tidak berwujud (intangible resources) ${ }^{21}$. Intangible resources dalam kerangka sistem manajemen kinerja dapat dikelompokkan menjadi tiga bagian yaitu:

a) Human Capital (Sumber Daya Insani)

b) Firm Equity

c) Technological Capital

d) Organizational capital

\section{Konsep Balanced Scorecard Dalam Pandangan Islam}

Balanced Scorecard (BSC) merupakan suatu konsep manajemen yang membantu menerjemahkan strategi perusahaan dalam suatu tindakan. BSC merupakan suatu sistem pengukuran kinerja manajemen atau sistem 
manajemen strategis yang diturunkan dari visi dan misi yang diwujudkan secara nyata dalam suatu bisnis. BSC merupakan suatu sistem pengukuran manajemen secara berimbang dari semua aspek akan dinilai yang tujuannya menciptakan value pada perusahaan.

Prinsip dasar dalam konsep BSC yaitu penilaian secara berimbang, sejalan dengan prinsip dasar manajemen dalam Islam yaitu adanya keadilan dalam setiap aspek manajemen. Namun, perlu digaris bawahi bahwa manajemen dalam Islam berlandaskan nilai-nilai spiritual dan kepedulian sosial sesama manusia. Dengan tujuan akhir tidak hanya mencapai kebahagian dunia, namun kebahagian akhirat. Sedangkan, teori BSC sendiri bertujuan menciptakan nilai tambah perusahaan dimata para stakeholder ataupun shareholder, dilihat dari empat aspek penilaian. Dimensi dunia yang lebih diutamakan, namun tidak ada nilai-nilai spiritual didalamnya ${ }^{22}$.

Terdapat beberapa penelitian terdahulu baik lokal meupun internasional tentang penerapan balanced scorecard (BSC) pada industri perbankan. Beberapa penelitian lokal yaitu penelitian dilakukan pada BPR di Bali. Hasil dari pengujian hipotesis komparatif menunjukkan bahwa terdapat perbedaan kinerja antara kedua BPR dan BPR Mitra Balijaya Mandiri ternyata lebih unggul ${ }^{23}$. Penelitian selanjutnya di penilaian kinerja dengan pendekatan BSC di Bank Sulawesi Utara. Hasilnya menunjukkan, perspektif keuangan sudah cukup baik, perspektif pelanggan dinilai sudah baik, perspektif proses bisnis internal dinilai cukup baik dan perspektif pertumbuhan serta pembelajaran dinilai masih kurang ${ }^{24}$. Penelitian tentang penerapan BSC pada BPR Nusumma di Blora. Hasilnya perspektif keuangan menunjukkan hasil yang baik, perspektif konsumen, tingkat kepuasan pelanggan dari $73 \%$, perspektif proses internal kinerja semakin baik, prespektif pertumbuhan dan pembelajaran ada peningkatan produktivitas karyawan ${ }^{25}$. Penelitian tentang penerapan BSC pada Bank Pasar Kabupaten Kudus. Hasilnya skor total BSC adalah sebesar 94,12\% dan masuk dalam kategori Sehat, dari segi keuangan dan pelanggan tergolong sehat, dan segi bisnis internal dan pertumbuhan cukup sehat ${ }^{26}$. Dan terakhir penelitian tentang environmenta/ BSC dan etika bisnis Islam. Disimpulkan, BSC mengharuskan pelaku bisnis menempati posisi antara prinsip untuk mendapat keuntungan dan kewajiban memelihara nilai-nilai moral masyarakat, karena Islam mengajarkan umatnya untuk melindungi dan menjaga alam dan lingkungan ${ }^{27}$.

Terdapat beberapa penelitian internasional yaitu penelitian yang berjudul "The Balanced Scorecard: Structure \& Potential Use in Malaysian Islamic Banks". Hasilnya terdapat hubungan positif antara balanced scorecard (BSC) 
dan shariah compliance (SC) terhadap organization performance (OP). Dimana OP yang semakin membaik dari 6 sampel bank yang diteliti dengan menggunakan BSC \& SC 28 . Penelitian dengan judul "Balanced Scorecard Approach for Better Shariah Corporate Governance". Hasilnya ada perbedaan yang mendasar antara Institut Keuangan Konvensional dengan Institut Keuangan Islam. Kepatuhan syariah (Shariah Compliance) adalah faktor yang sangat membedakan antara keduanya. Hal ini akan menarik bagi Shariah advisors, industrial players, regulators, researchers dan general public ${ }^{29}$. Peneliti dengan judul "Identifying Key Performance Indicators of an Iranian Islamic Bank Based on BSC and AHP". Hasil penelitian ini dapat berkontribusi untuk lebih meningkatkan kompetisi industri berbankan yang berfokus pada efesiensi dan profit keuangan bank ${ }^{30}$.

Perbedaan penelitian ini dengan beberapa penelitian lokal dan internasional adalah alat analisis atau uji statistik yang digunakan. Beberapa penelitian internasional menjelaskan juga dengan pendekatan shariah complaint. Dan ini tidak ditemukan dalam penelitian sekarang, hanya saja diakhir pembahasan terdapat penjelasan terkait pandangan Islam mengenai kinerja perusahaan dengan pendekatan balanced scorecard. Perbedaan dengan penelitian lokal adalah pada objek penelitian yaitu lembaga keuangan berbasis syariah dan jumlah responden yang digunakan pada prespektif konsumen, bisnis internal, pembelajaran serta pertumbuhan. Dengan harapan penelitian ini mampu menjelaskan secara lebih mendalam.

Berikut kerangka pemikiran peneliti, terlihat pada gambar dibawah ini:

\section{Gambar 2.1 Kerangka Pemikiran}

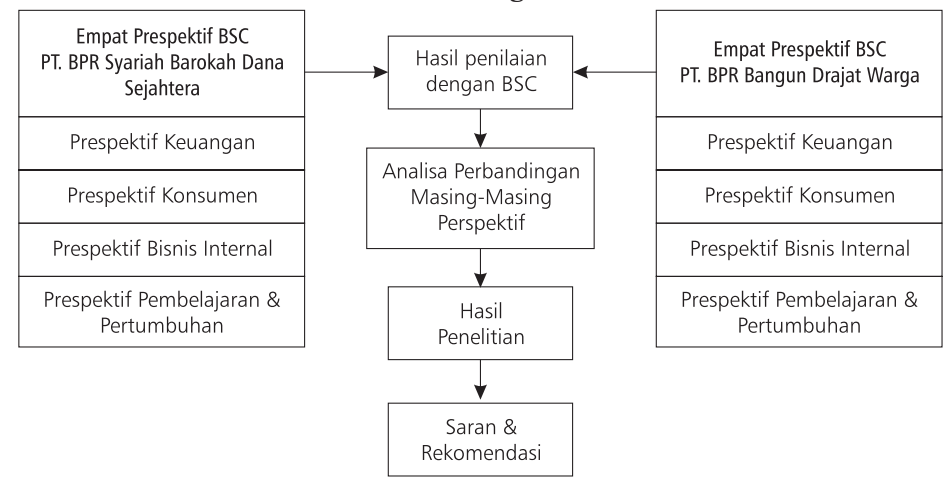




\section{METODE PENELITIAN}

Jenis penelitian yang digunakan adalah penelitian deskriptif. Adapun desain penelitian yang digunakan berbentuk komparatif atau perbandingan. Dengan desain penelitian komparatif, penulis mengadakan penelitian dengan terjun langsung ke lapangan, mencatat kemudian menganalisa kinerja perusahaan dari dua objek penelitian yaitu di BPRS Barokah Dana Sejahtera dan BPRS Bangun Drajat Warga kemudian dibandingkan dengan pendekatan konsep balanced scorecard.

Populasi dalam penelitian ini adalah seluruh BPRS di Yogyakarta yang berjumlah sebelas BPRS, tiga BPRS berada di Kota Yogyakarta, tiga BPRS berada di Kabupaten Bantul dan enam BPRS di Kabupaten Sleman. Untuk menentukan sampel penelitian, peneliti menggunakan teknik purposive sampling, yaitu teknik pengambilan sampel dengan pertimbangan dan kriteria tetentu sesuai tujuan penelitian. Kriteria sampel penelitian tercantum pada tabel dibawah ini:

Tabel 3.1 Kriteria Pengambilan Sampel Penelitian

\begin{tabular}{|c|c|c|c|c|c|}
\hline \multirow{3}{*}{ Wilayah } & \multirow{3}{*}{ Nama BPRS } & \multicolumn{4}{|c|}{ KRITERIA } \\
\hline & & Total Aktiva & Laba Bersih & Jumlah Kantor & \\
\hline & & Des 2014 & Des 2014 & Pusat/Cab/Kas & \\
\hline \multirow{4}{*}{$\begin{array}{l}\text { Kota } \\
\text { Yogyakarta }\end{array}$} & Barokah Dana Sejahtera & $56,956,440$ & $1,171,640$ & 3 unit & $\mathrm{v}$ \\
\hline & Dana Hidayatullah & $19,649,988$ & 692,657 & 2 unit & - \\
\hline & Mita Harmoni & $16,054,212$ & 147,982 & 1 unit & - \\
\hline & Bangun Drajat Warga & $53,909,789$ & $1,118,447$ & 4 unit & v \\
\hline \multirow[t]{4}{*}{ Kab. Bantul } & Mitra Mandiri Sejahtera & $32,241,060$ & 960,970 & 2 unit & - \\
\hline & Margirizki Bahagia & $42,751,494$ & $1,048,254$ & 2 unit & - \\
\hline & Cahaya Hidup & $4,560,932$ & 245,943 & 1 unit & - \\
\hline & Danagung Syariah & $22,899,934$ & 803,053 & 2 unit & - \\
\hline \multirow[t]{3}{*}{ Kab. Sleman } & FORMES & $24,816,572$ & 270,444 & 2 unit & - \\
\hline & Mitra Amal Mulia & $24,922,896$ & 575,115 & 1 unit & - \\
\hline & Mitra Cahaya Indonesia & $8,864,247$ & 748,461 & 1 unit & - \\
\hline
\end{tabular}

Sumber: Data Sekunder

Adapun lokasi yang menjadi objek dalam penelitian ini adalah:

Lokasi pertama terletak di Kantor Pusat PT. BPR Syariah Barokah Dana Sejahtera Jl. Sisingamangaraja, No. 71 Mergangsan Yogyakarta. Waktu penelitian dimulai tanggal 16 Maret 2015 hingga 09 April 2015. Penelitian lapangan mengikuti jam kantor pelayanan bank, mulai jam 08.00 hingga jam 15.00 WIB, terkecuali pada hari Sabtu pukul 08.00 - 11.00 WIB.

Lokasi kedua terletak di Kantor Pusat PT. BPR Syariah Bangun Drajat Wraga Jl. Gedong Kuning Selatan, No. 131 A Yogyakarta. Waktu penelitian dimulai tanggal 17 April 2015 hingga 09 Mei 2015. Penelitian lapangan mengikuti 
jam kantor pelayanan bank, mulai jam 08.00 hingga jam $15.00 \mathrm{WIB}$, terkecuali hari Sabtu pukul $08.00-11.00$ WIB.

Teknik pengumpulan data merupakan langkah yang paling utama dalam penelitian, karena tujuan utama dari penelitian adalah mendapatkan data. Sumber data yang digunakan pada penelitian ini yaitu data sekunder dan data primer. Data sekunder yaitu laporan keuangan, data primer berupa hasil kuesioner, hasil wawancara dan dokumentasi.

Adapun Instrumen yang digunakan dalam Penelitian ini adalah:

\section{Prespektif Keuangan}

Tabel 3.2 Variabel dan Ukuran Variabel Prespektif Keuangan

\begin{tabular}{|c|c|}
\hline VARIABEL & UKURAN VARIABEL \\
\hline Permodalan (Capital) & CAR/KPMM \\
\hline $\begin{array}{l}\text { Aktiva Produktif (Assets } \\
\text { Quality) }\end{array}$ & Non Performing Financing (NPF) dan PPAP \\
\hline Profitabilitas (Earning) & $\begin{array}{l}\text { Rasio Return on Assets (ROA), Return on } \\
\text { Equity (ROE) dan BOPO (Biaya Operasional } \\
\text { dan Pendapatan Operasional) }\end{array}$ \\
\hline Likuiditas (Liquidity) & Financing to Deposit Ratio (FDR) \\
\hline
\end{tabular}

\section{Prespektif Konsumen (Nasabah)}

Tabel 3.3 Variabel dan Ukuran Variabel Prespektif Konsumen

\begin{tabular}{ll}
\hline VARIABEL & UKURAN VARIABEL \\
\hline Product and Service & Price (Harga), Quality (Kualitas) dan Time \\
Attrubite & (Waktu) \\
Relationship & Convinient (Kemudahan), Trusted \\
& (Kepercayaan) dan Responsive (Daya \\
& Tanggap) \\
Image & Image dan Reputasi Bank \\
\hline
\end{tabular}

Sumber: Diadaptasi dari teori BSC Kaplan \& Norton, Translating Strategy in to Action the Balanced Scorecard, 1996, hlm. 74.

\section{Prespektif Bisnis Internal}

Dalam kuesioner bisnis internal terdapat tiga variabel pengukuran. Pertama, pertanyaan mengenai proses inovasi, kedua pertanyaan mengenai proses operasi, ketiga pertanyaan mengenai manajemen dan pertanyaan tentang layanan purna jual untuk mengetahui apakah bank menjaga fasilitas, evaluasi terhadap produk/jasa dan pelayanan kepada nasabah ${ }^{31}$.

Proses operasi yang berkaitan dengan aktivitas pelayanan kepada nasabah. 
Dan pengukurannya dapat dilakukan dengan menggunakan rasio AETR ( $\mathrm{Ad}$ ministrative Expense to Total Revenue) yang bertujuan untuk mengetahui efisiensi dan efektivitas serta ketetapan waktu proses atas transaksi yang dilakukan bank. Rumusnya dapat dilihat dibawah ini32:

$$
\text { ATER }=\frac{\text { Biaya Administrasi }}{\text { Total Pendapatan }} \times 100 \%
$$

\section{Prespektif Pembelajaran \& Pertumbuhan}

Dirangkum pada tabel dibawah ini, yaitu:

Tabel 3.4 Variabel dan Ukuran Variabel Learn and Growth Prespective

\begin{tabular}{|c|c|}
\hline VARIABEL & UKURAN VARIABEL \\
\hline Human Capital & Kemampuan dan Kepuasan Karyawan \\
\hline Information Capital & Sistem Informasi dan Teknologi \\
\hline Organization Capital & Motivasi, Kepemimpinan dan Kerjasama Tim \\
\hline
\end{tabular}

\section{METODE ANALISA DATA}

\section{Uji Instrumen}

Uji validitas pada penelitian ini menggunakan Confirmatory Factor Analysis (CFA). Analisis ini digunakan untuk mengetahui apakah suatu konstruk memiliki unidimesionalitas atau apakah indikator-indikator yang digunakan dapat mengkonfirmasi sebuah variabel atau konstruk ${ }^{33}$. Suatu kuesioner dikatakan reliabel atau handal jika jawaban seseorang terhadap pertanyaan adalah konsisten atau stabil dari waktu ke waktu. Uji reabilitas yaitu dengan cronbach alpha. Suatu konstruk atau variabel dinyatakan reliabel jika memberikan nilai cronbach alpha $>0.70^{34}$. Sedangkan, uji normalitas yang digunakan yaitu dengan uji kolmogorov smirnov (Uji K-S) dengan probabilitas á $=0.05$, jika nilai K-S lebih besar dari 0.05 maka data tersebut terdistribusi normal.

Hasil uji validitas kuesioner prespektif konsumen (nasabah) dan prespektif pembelajaran dan pertumbuhan semua dinyatakan valid karena $>0.50$. Begitu halnya hasil uji reabilitas kuesioner prespektif konsumen dan pembelajaran serta pertumbuhan semua reliabel karena $>0.70$. Namun, pada prespektif bisnis internal tidak lulus uji validitas dan uji reabilitas. Untuk prespektif keuangan semua data terdistribusi normal.

\section{Analisis Perbandingan}

a. Prespektif Keuangan 
Tabel 3.5 Rangkuman Metode Penelitian

\begin{tabular}{|c|c|c|c|c|c|}
\hline $\begin{array}{l}\text { PRESPEKTIF } \\
\text { BSC }\end{array}$ & $\begin{array}{l}\text { POPULASI \& } \\
\text { SAMPEL } \\
\text { PENELITIAN }\end{array}$ & $\begin{array}{l}\text { TEKNIK } \\
\text { SAMPLING }\end{array}$ & SUMBER DATA & UIIINSTRUMEN & ANALISIS DATA \\
\hline Keuangan & $\begin{array}{l}\text { Data } \\
\text { keuangan } \\
2012-2014 .\end{array}$ & $\begin{array}{l}\text { Sampling } \\
\text { Purposive }\end{array}$ & $\begin{array}{l}\text { Data Sekunder } \\
\text { berupa Laporan } \\
\text { Keuangan 2012- } \\
2014\end{array}$ & $\begin{array}{l}\text { Uji Normalitas } \\
\text { (Uji K-S) }\end{array}$ & $\begin{array}{l}\text { Statistik } \\
\text { Parametrik, Uji } \\
\text { Independent } \\
\text { Sample } t-\text { test }\end{array}$ \\
\hline Konsumen & $\begin{array}{l}\text { Rumus Isaac \& } \\
\text { Michael untuk } \\
\text { menentukan } \\
\text { sampel }\end{array}$ & $\begin{array}{l}\text { Icidental } \\
\text { Sampling }\end{array}$ & $\begin{array}{l}\text { Data Primer dari } \\
\text { Kuesioner }\end{array}$ & $\begin{array}{l}\text { Uji Validitas - Uji } \\
\text { CFA \& Uji } \\
\text { Reabilitas - Nilai } \\
\text { Cronbach Alpha }\end{array}$ & $\begin{array}{l}\text { Statistik Non- } \\
\text { Parametrik, Uji } \\
\text { Mann Whitney U }\end{array}$ \\
\hline Bisnis Internal & $\begin{array}{l}\text { Direktur \& } \\
\text { Beberapa } \\
\text { kepala devisi } \\
\text { utama }\end{array}$ & $\begin{array}{l}\text { Sampling } \\
\text { Purposive }\end{array}$ & $\begin{array}{l}\text { Data Primer \& } \\
\text { Wawancara }\end{array}$ & $\begin{array}{l}\text { Uji Validitas - } \\
\text { Pearson } \\
\text { Correlation \& Uji } \\
\text { Reabilitas - Nilai } \\
\text { Cronbach Alpha }\end{array}$ & $\begin{array}{l}\text { Statistik Non- } \\
\text { Parametrik, Uji } \\
\text { Mann Whitney U }\end{array}$ \\
\hline $\begin{array}{l}\text { Pembelajaran \& } \\
\text { Pertumbuhan }\end{array}$ & $\begin{array}{l}\text { Seluruh } \\
\text { Karyawan }\end{array}$ & $\begin{array}{l}\text { Icidental } \\
\text { Sampling }\end{array}$ & $\begin{array}{l}\text { Data Primer dari } \\
\text { Kuesioner }\end{array}$ & $\begin{array}{l}\text { Uji Validitas - Uji } \\
\text { CFA \& Uji } \\
\text { Reabilitas Nilai } \\
\text { Cronbach Alpha }\end{array}$ & $\begin{array}{l}\text { Statistik Non- } \\
\text { Parametrik, Uji } \\
\text { Mann Whitney U }\end{array}$ \\
\hline
\end{tabular}

Sumber: Penulis

Perbedaan kinerja keuangan dengan membandingkan rasio keuangan, posisi aktiva, pasiva dan laba/rugi. Uji statistik yang digunakan yaitu independent sample t-test, karena data terdistribusi normal. Pengambilan keputusan, melihat nilai signifikansi jika lebih besar dari 0.05 (á: 5\%), maka diterima yang artinya terdapat perbedaan.

b. Prespektif Konsumen (Nasabah)

Perbedaan prespektif konsumen antara kedua BPRS dengan membandingkan tiga variabel yaitu Product and Service Attrubite, Relationship serta Image kedua bank. Untuk melihat perbedaan prespektif konsumen menggunakan uji Mann Whitney $U$, karena data berdistribusi tidak normal sehingga menggunakan statistik non-parametrik. Pengambilan keputusan melihat nilai U (U test), jika nilai U hitung lebih kecil dari nilai probabilitas 0.01 atau 0.05 (á: $1 \%$ atau 5\%), maka diterima.

c. Prespektif Pembelajaran \& Pertumbuhan

Perbedaan prespektif pertumbuhan dan pembelajaran antara kedua BPRS dengan membandingkan variabel kemampuan karyawan, kepuasan karyawan, motivasi kerja, kepemimpinan dan kerjasama tim dari hasil kuesioner dari kedua bank dan alat ujinya yaitu Mann Whitney $U$.

d. Prespektif Bisnis Internal

Perbedaan prespektif bisnis internal antara kedua BPRS dengan membandingkan variabel proses inovasi, proses operasi, sistem manajemen dan proses purna jual dari kedua bank dan alat ujinya yaitu Mann Whitney $U$. 


\section{PROFIL UMUM BPRS BAROKAH DANA SEJAHTERA}

Surat izin pendirian pada tanggal 10 Oktober 2007 dari Bank Indonesia dengan nomor 9/51/KEP. GBI/2007. Soft Opening dilaksanakan pada tanggal 1 November 2007, selanjutnya pada tanggal 14 November 2007 BPRS BDS diresmikan oleh Pimpinan Bank Indonesia Yogyakarta yaitu Ibu Endang Setyadi dan disaksikan oleh Sekda Kota Yogyakarta. Pada tanggal 6 Febuari 2009 diselenggaran Rapat Umum Pemegang Saham pertama tahun buku 2008.

Visi bank syariah BDS adalah menjadi lembaga perbankan syariah yang besar dan sehat serta memberi kemanfaatan pada ummat. Dan misi bank syariah BDS adalah:

a. Melakukan operasional perbankan secara kompetitif, efisien dan memenuhi prinsip kehati-hatian,

b. Memberikan pelayanan prima dan optimal kepada nasabah,

c. Mengembangkan dan menumbuhkan sektor riil berbasis bagi hasil (share based financing),

d. Mengembangkan sumberdaya manusia berdasarkan apek profesionalitas dan spiritualitas,

e. Mengembangkan prinsip keseimbangan dalam semua aspek termasuk pemenuhan hak bagi seluruh stakeholder,

f. Bekerjasama dengan perbankan syariah lainnya menuju kebaikan dan kemaslahatan ummat.

\section{PROFIL UMUM BPRS BANGUN DRAJAT WARGA}

Pada hari Rabu, 02 Pebruari 1994 telah berdiri PT. BPRS Bangun Drajat Warga yang berkedudukan di Ngipik, Baturetno, Banguntapan, Bantul dan diresmikan oleh Ketua Pimpinan Pusat Muhammadiyah waktu itu Bapak KH. Akhmad Azhar Basyir, MA.

Visi BPRS BDW adalah menjadikan BPRS BDW sebagai lembaga keuangan syariah yang unggul dan terpercaya. Sedangkan, misi yang ingin dicapai BPRS BDW yaitu:

a) Mengembangkan dan mensosialisasikan pola, sistem dan konsep perbankan syariah.

b) Memajukan BPRS BDW dengan prinsip bagi hasil yang saling menguntungkan antara nasabah dan BPRS BDW dalam kerangka amar ma'ruf nahi munkar.

c) Mendapatkan profit sesuai dengan target yang ditetapkan.

d) Memberikan kesejahteraan kepada pengguna jasa, pemilik, pengurus dan pengelola BPRS BDW secara layak. 


\section{KONDISI UMUM BPRS BAROKAH DANA SEJAHTERA}

\section{Gambar 4.1 Grafik Pertumbuhan Aktiva dan Laba Bersih BPRS BDS}

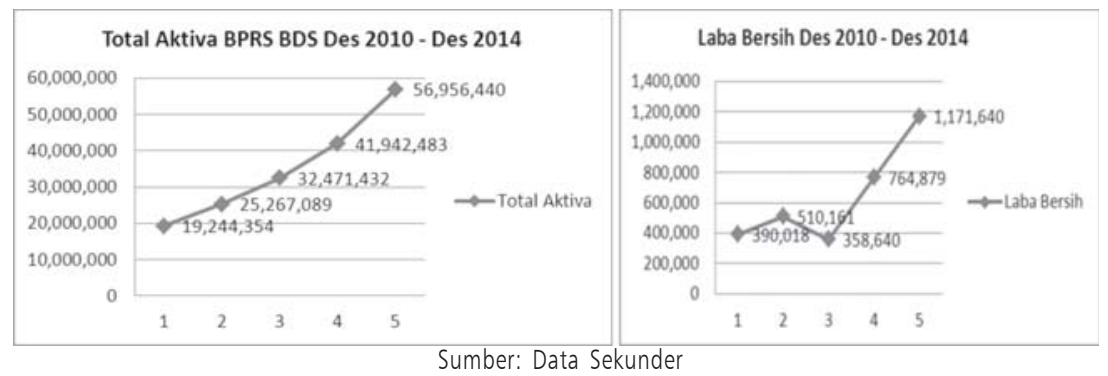

Pada Gambar 4.1 menunjukkan total aktiva BPRS BDS terus mengalami pertumbuhan yang cukup signifikan, hal ini terlihat dari grafik diatas. Total aktiva hingga Desember 2014 mengalami peningkatan dari Desember 2013 sebesar Rp 15,013,957 miliar menjadi Rp 56,956,440 miliar. Sedangkan, untuk laba bersih pada Desember 2012 mengalami penurunan laba bersih menjadi Rp 358,640, namun memasuki tahun 2013 dan 2014 laba bersih terus meningkat hingga mencapai Rp 1,171,640 pada Desember 2014 meningkat sebesar Rp 406,761 dari tahun lalu.

\section{Gambar 4.2 Grafik Pertumbuhan DPK \& Penyaluran Dana BPRS BDS}

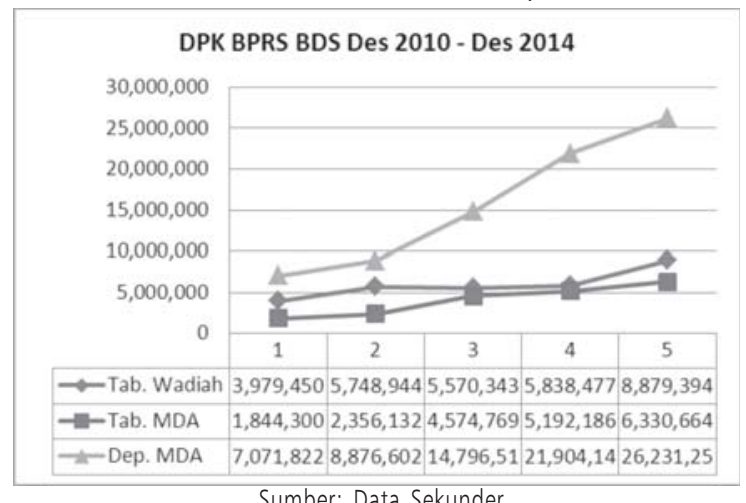

Pada Gambar 4.2 menunjukkan total dana pihak ketiga (DPK) BPRS BDS terus mengalami pertumbuhan yang cukup signifikan, hal ini terlihat dari grafik diatas. Tabungan wadiah terus meningkat, pada Desember 2014 menjadi Rp 8,879,934 miliar meningkat sebesar Rp 3,040,917 miliar dari tahun sebelumnya. Tabungan mudharabah terus meningkat meskipun tidak signifikan, 
hingga Desember 2014 mencapai Rp 6,330,664 miliar meningkat sebesar Rp $1,138,478$ dari tahun sebelumnya. Sama halnya dengan produk tabungan, untuk deposito di BPRS BDS pada Desember 2014 mencapai Rp 26,231,250 miliar meningkat sebesar Rp 4,327,110 miliar dari tahun sebelumnya.

\section{KONDISI UMUM BPRS BANGUN DRAJAT WARGA}

\section{Gambar 4.3 Grafik Pertumbuhan Aktiva dan Laba Bersih BPRS BD}

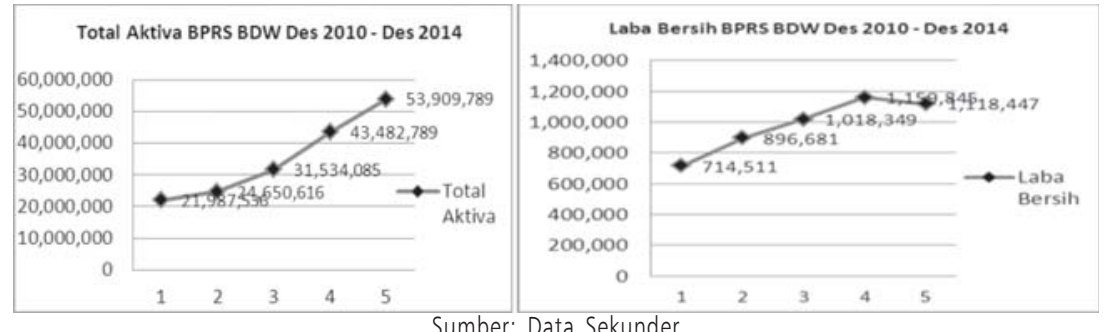

Gambar 4.4 Grafik Penyaluran Dana \& Pertumbuhan DPK BPRS BDW

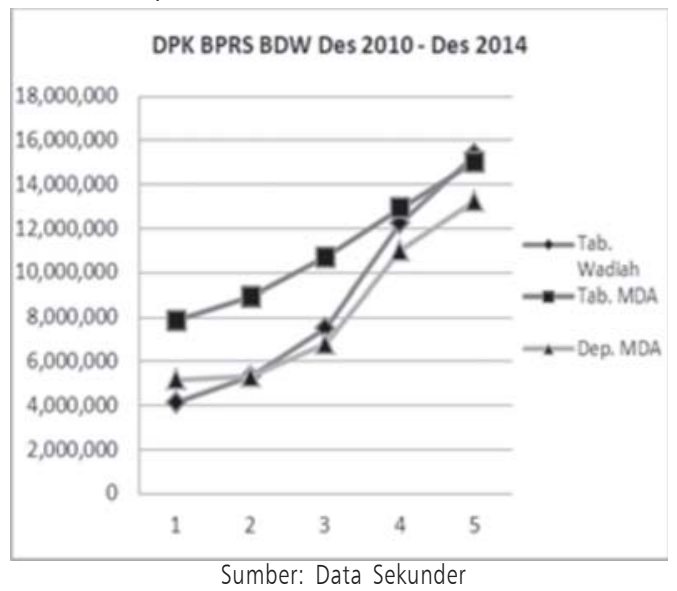

Pada Gambar 4.3 menunjukkan total aktiva BPRS BDW terus mengalami peningkatan hingga Desember 2014. Total aktiva hingga Desember 2014 rupanya naik dari Desember 2013 sebesar Rp 10,427,000 milyar menjadi Rp 53,900,789 milyar. Laba bersih BPRS BDW selama Dsember 2010 hingga Desember 2014 terus mengalami peningkatan, namun tidak pada Desember 2014 yang mengalami penurunan sebesar Rp 41,398 dari Desember 2013 menjadi Rp 1,118,447. Berdasarkan hasil wawancara dengan wakil direktur penurunan tersebut disebabkan oleh beberapa hal yaitu biaya yang dikeluarkan untuk pembukaan kantor cabang mempengaruhi performa keuntungan yang 
diperoleh bank, kedua adanya target pembiayaan yang tidak tercapai, dan terakhir biaya rekrutmen SDM selama 2014 mengalami peningkatan.

Pada Gambar 4.4 menunjukkan total dana pihak ketiga (DPK) BPRS BDW terus mengalami pertumbuhan cukup signifikan. Tabungan wadiah, pada Desember 2014 menjadi Rp 15,350,676 milyar meningkat sebesar Rp 3,090,950 miliar dari tahun sebelumnya. Tabungan mudharabah, hingga Desember 2014 mencapai Rp 15,028,900 milaar meningkat sebesar Rp 2,095,414 miliar dari tahun sebelumnya. Sama halnya dengan produk tabungan, untuk deposito pada Desember 2014 mencapai Rp 13,250,005 miliar meningkat sebesar Rp 2,240,940 miliar dari tahun sebelumnya.

\section{KINERJA BPRS BAROKAH DANA SEJAHTERA PENDEKATAN BALANCED SCORECARD}

\section{a. Prespektif Keuangan}

Analisa rasio keuangan dengan metode CAMEL yang digunakan yaitu penilaian permodalan dengan rasio KPMM, penilaian profitabilitas dengan rasio $\mathrm{ROA}$, ROE, dan BOPO, penilaian aktiva produktif dengan rasio NPF dan PPAP, dan terakhir penilaian likuiditas dengan rasio FDR. Berdasarkan hasil penilaian tingkat kesehatan, semua rasio keuangan BPRS BDS dinilai memiliki predikat baik meskipun ada koreksi pada rasio FDR yang dinilai kurang baik.

Hasil analisa trend pada laporan neraca menunjukkan trend meningkat sepanjang tahun 2012-2013 pada kas dan total aktiva, namun di tahun 2014 menurun, meskipun trend pembiayaan terus meningkat sepanjang tiga periode. Total DPK trend terus meningkat sepanjang 2012-2014. Sedangkan, untuk bagi hasil dan laba bersih, trend cenderung menurun diakhir 2014.

b. Prespektif Konsumen

Hasil kuesioner tiga atribut prespektif konsumen, lebih dari 50\% nasabah menjawab setuju dengan produk/jasa yang ditawarkan bank. Kepercayaan nasabah kepada BPRS BDS memiliki prosentase tertinggi yaitu 85.20\% dan terendah pada atribut kualitas 81.43\&. Rata-rata market share BPRS BDS selama 2012-2014 yaitu sebesar $15.88 \%$.

\section{c. Prespektif Bisnis Internal}

Hasil kuesioner atribut prespektif bisnis internal, responden dari direktur dan beberapa devisi menjawab setuju dengan pertanyaan yang diajukan terkait proses inovasi, operasi, manajemen dan layanan purna jual. Proses operasi memiliki prosentase tertinggi yaitu $75.43 \%$ dari atribut lainnya. Rata-rata rasio AETR BPRS BDS selama 2012-2014 yaitu sebesar $11.85 \%$. 


\section{d. Prespektif Pembelajaran dan Pertumbuhan}

Hasil kuesioner atribut prespektif pembelajaran dan pertumbuhan, responden berasal dari karyawan bank. Pertanyaan mengenai informasi dan teknologi serta kerjasama tim memiliki prosentase terendah yaitu $77.17 \%$ dan $79.70 \%$. Skor rata-rata skala linkert yaitu 3.86 dan 3.98, artinya beberapa responden kurang setuju dengan sistem teknologi, informasi dan kerjasama tim yang diterapkan perusahaan.

\section{KINERJA PERUSAHAAN BPRS BANGUN DRAJAT WARGA PENDEKATAN BALANCED SCORECARD}

a. Prespektif Keuangan

Analisa rasio keuangan dengan metode CAMEL yang digunakan yaitu penilaian permodalan dengan rasio KPMM, penilaian profitabilitas dengan rasio $R O A, R O E$, dan $B O P O$, penilaian aktiva produktif dengan rasio NPF dan PPAP, dan terakhir penilaian likuiditas dengan rasio FDR. Berdasarkan hasil penilaian tingkat kesehatan, semua rasio keuangan BPRS BDW dinilai memiliki predikat baik. Namun, rasio NPF harus segera diperbaiki karena menunjukkan angka pembiayaan bermasalah dibannk tersebut cukup tinggi.

Hasil analisa trend pada laporan neraca menunjukkan trend meningkat sepanjang tahun 2012-2013 pada kas, total aktiva dan pembiayaan namun di kuartal kedua hingga keempat tahun 2014 menurun. Total DPK trend terus meningkat sepanjang 2012-2013, menurun di 2014. Sedangkan, untuk bagi hasil dan laba bersih, trend cenderung menurun diakhir 2014.

b. Prespektif Konsumen

Hasil kuesioner tiga atribut prespektif konsumen, lebih dari 50\% nasabah menjawab setuju dengan produk/jasa yang ditawarkan bank. Kepercayaan nasabah kepada BPRS BDW memiliki prosentase tertinggi yaitu 85.16\% dan atribut terendah pada kualitas sebesar $80.50 \%$. Rata-rata market share BPRS BDW selama 2012-2014 yaitu sebesar 15.62\%.

c. Prespektif Bisnis Internal

Hasil kuesioner atribut prespektif bisnis internal, responden dari direktur dan beberapa devisi menjawab setuju dengan pertanyaan yang diajukan terkait proses inovasi, operasi, manajemen dan layanan purna jual. Proses operasi memiliki prosentase tertinggi yaitu $85.15 \%$ dari atribut lainnya. Rata-rata rasio AETR BPRS BDW selama 2012-2014 yaitu sebesar 13.13\%.

d. Prespektif Pembelajaran dan Pertumbuhan

Hasil kuesioner atribut prespektif pembelajaran dan pertumbuhan, 
responden berasal dari karyawan bank. Pertanyaan mengenai informasi dan teknologi, kepemimpinan dan motivasi memiliki prosentase rendah yaitu 83.43\%, 83.54\% dan 83.64\% dari atribut lainnya. Skor rata-rata skala linkert yaitu 3.82, 3.83 dan 3.83 artinya beberapa responden kurang setuju dengan sistem teknologi, informasi, gaya kepemimpinan dan motivasi yang diterapkan perusahaan. Secara keseluruhan prespektif pembelajaran dan pertumbuhan BPRS BDS lebih unggul dari BPRS BDW.

\section{PERBANDINGAN KINERJA KEDUA BPRS}

Hasil dari keempat prespektif BCS masing-masing BPRS kemudian dilakukan uji beda dengan bantuan program SPSS versi 20, dan hasilnya telah dirangkum pada tabel di bawah ini:

Tabel 4.5 Hasil Uji Beda Keempat Prespektif BSC

\begin{tabular}{|c|c|c|}
\hline \multirow[t]{4}{*}{$\begin{array}{l}\text { Perbandingan } \\
\text { Kedua BPRS }\end{array}$} & Keuangan & $\begin{array}{l}\text { BERBEDA SIGNIFIKAN: NPF, KPMM, FDR, Kas, Pmby. MDA, } \\
\text { Pmby. MSR, Piu. Multijasa, Bagi Hasil, Kewjiban Segera, } \\
\text { DPK. } \\
\text { TIDAK BERBEDA: PPAP, ROA, ROE, BOPO, Piutang MRB, } \\
\text { Total Aktiva, Pend OPS, Beban OPS, Laba Bersih, Aktiva Pro. }\end{array}$ \\
\hline & Konsumen & $\begin{array}{l}\text { Semua atribut penilaian tidak memiliki perbedaan antara } \\
\text { kedua BPRS. Hanya saja market share BPRS BDS lebih } \\
\text { unggul } 0.26 \% \text { dari BPRS BDW. Kualitas produk/jasa hasil } \\
\text { kuesioner kedua BPRS lebih rendah dari indikator lain, } \\
\text { untuk itu harus ada evaluasi pada kualitas produk/jasa agar } \\
\text { lebih mampu bersaing dengan bank lainnya. }\end{array}$ \\
\hline & Bisnis Internal & $\begin{array}{l}\text { Semua atribut penilaian tidak memiliki perbedaan. Hanya } \\
\text { saja rasio AETR BPRS BDW lebih tinggi dari BPRS BDS. } \\
\text { Artinya ketepatan proses transksi BPRS BDW lebih unggul } \\
\text { dari BPRS BDS. }\end{array}$ \\
\hline & $\begin{array}{l}\text { Pembelajaran \& } \\
\text { Pertumbuhan }\end{array}$ & $\begin{array}{l}\text { Semua atribut tidak memiliki perbedaan. Sedikit koreksi } \\
\text { pada sistem informasi dan teknologi kedua BPRS masih } \\
\text { sama-sama memiliki kekurangan. Hasil kuesioner } \\
\text { menunjukkan organization capital BPRS BDS terlihat lebih } \\
\text { unggul dibanding BPRS BDW. }\end{array}$ \\
\hline
\end{tabular}

Sumber: Penulis

\section{KETERKAITAN KEEMPAT PRESPEKTIF BALANCED SCORECARD}

Hasil penelitian kinerja perusahaan BPRS Barokah Dana Sejahtera dengan pendekatan BSC menunjukkan bahwa organization capital berupa kerjasama tim dirasa masih cukup begitu halnya dengan information capital. Hal ini berkaitan dalam membentuk image atau reputasi bank dimata nasabah. Dalam konsep BSC, image dan reputasi bank berkaitan dengan kepuasan nasabah, sehingga mereka bisa saja beralih ke bank lain karena tidak puas dengan sistem layanan yang ditawarkan bank. Dan jika dibiarkan tentunya mengganggu 
performa keuangan bank. Berkaiatan dengan kerjasama tim, BPRS BDS telah memiliki tim khusus untuk membentuk karyawan agar tetap profesional dan religius dalam bekerja. Sehingga, diharapkan visi, misi, budaya kerja serta strategi perusahaan tercapai dengan baik.

Hasil penelitian kinerja perusahaan BPRS Bangun Darajat Warga dengan pendekatan BSC menunjukkan bahwa kompenen penilaian prespektif pembelajaran dan pertumbuhan masih dirasa kurang, sesuai hasil jawaban responden. Sumber daya manusia dalam organisasi merupakan aset paling berharga dalam menentukan sukses atau tidaknya sebuah organisasi. Dalam konsep BSC, hal ini akan mempengaruhi sistem bisnis internal perusahaan. Kinerja internal perusahaan yang kurang, tentunya akan mengganggu performa layanan kepada nasabah. Dan jika tidak segera dievaluasi bisa berimbas langsung kepada performa keuangan. Pada akhirnya visi, misi dan strategi perusahaan tidak tercapai sebagaimana mestinya.

\section{BALANCED SCORECARD DALAM PANDANGAN ISLAM}

\section{Prespektif Keuangan}

Prestasi dalam keuangan merupakan hal penting bagi industri perbankan, karena bank termasuk industri bisnis yang juga mencari keuntungan untuk keberlangsungan usahanya. Bagi perbankan syariah, hal yang harus diperhatikan dalam mencapai keuntungan yaitu kaidah dan etika bisnis bisnis Islam. Kaidah hukum asal muamalah sendiri menyatakan: segala sesuatunya dibolehkan kecuali ada larangan dalam al-Qur'an dan as-Sunnah. Sedangkan, etika bisnis Islam harus mengandung empat hal yaitu tauhid (QS. Al-An'am: 162), keseimbangan (QS. Al-Hadid: 25), kehendak bebas (QS. Al-Mudasir: 38) dan pertanggung jawaban ${ }^{35}$. Untuk itu perbankan syariah seharusnya tidak sematamata mencari keuntungan belaka, namun aspek mardhatillah serta kemaslahatan umat.

Dalam teori balanced scorecard, prestasi keuangan tidak akan tercapai tanpa dukungan konsumen, bisnis internal, pembelajaran, serta pertumbuhan dan harus dijalankan secara seimbang agar para pihak-pihak yang berkepentingan puas dengan kinerja perusahaan. Prinsip keseimbangan juga diterapkan dalam bisnis Islami, namun dimensi akhir yang dituju adalah akhirat bukan sebatas dunia. BPRS BDS dan BPRS BDW merupakan lembaga keuangan syariah, penerapan nilai-nilai dan etika bisnis Islami seyogyanya dijalankan secara konsisten dalam semua aktifitas bank dan juga dijalankan setiap anggota perusahaan dalam kehidupan kesehariannya. Sehingga, dalam mencapai tar- 
get keuangan tidak berfokus kepada keuntungan, namun bagaimana bermanfaat bagi kemaslahatan umat.

\section{Prespektif Konsumen (Nasabah)}

Konsumen merupakan stakeholder yang hakiki dalam bisnis. Bisnis tidak mungkin berjalan tanpa ada konsumen yang menggunakan produk/jasa yang ditawarkan oleh pebisnis. Supaya bisnis terus berjalan, konsumen perlu memakai atau memanfaat produk/jasa tersebut. Para konsumen yang pada akhirnya memainkan peranan dalam menentukan keuntungan yang dicapai perusahaan. Maka, perusahaan harus bisa memperoleh, mempertahankan, serta menjaga kepercayaan para konsumen ${ }^{36}$.

Dalam teori balanced scorecard untuk memperoleh, mempertahankan dan menjaga kepercayaan kosumen dengan meningkatkan pangsa pasar, kualitas produk/jasa, menjalin hubungan baik dan menjaga reputasi bank. Dalam pandangan Islam, semua itu harus berangkat dari nilai-nilai moralitas para pelaku bisnis. Implementasi nilai-nilai moralitas tersebut merupakan tanggung jawab pelaku bisnis, hasil refleksi keimanannya kepada Allah SWT ${ }^{37}$. Nilai-nilai moral misalnya kejujuran, keadilan, amanah, berniat baik, menepati janji dan lainnya. Jika, para pelaku bisnis konsisten menjalankan, maka mudah memperolehnya meskipun banyak menghadapi aturan dan kendala.

\section{Prespektif Bisnis Internal}

Bisnis internal disini berkaitan dengan bagaimana kegiatan internal perusahaan dapat dijalankan dengan baik. Perencanaan dan organisasi perusahaan yang baik sangat mempengaruhi dalam menghasilkan kualitas perusahaan.

Dalam Islam organisasi memiliki stuktur kepemimpinan yang terdiri dari beberapa level dan memiliki hubungan antara atasan dan bawahan. Adanya strata kepemimpinan bukan berarti setiap pemimpin terpisah. Karena, kedudukan mereka satu wadah manajemen yang disusun berdasarkan konsep syura, sehingga harus saling berkontribusi untuk mencapai tujuan organisasi. Perbedaan level pekerjaan dan kepemimpinan dalam Islam, didasarkan pada ilmu pengetahuan, intelektual atau pengalaman teknis. Struktur organisasi BPRS terdiri dari beberapa devisi yang dikepalai seorang direktur sebagai top management, diharapkan adanya hubungan baik antara atasan dengan bawahan. 


\section{Prespektif Pembelajaran dan Pertumbuhan}

Prespektif pembelajaran dan pertumbuhan bersumber dari faktor sumber daya manusia. Dalam organisasi manusia adalah sumber daya utama. Prespektif pembelajaran dan pertumbuhan adalah fondasi utama keberhasilan organisasi ${ }^{38}$. Prespektif ini berkaitan dengan kemampuan, kepuasan, motivasi, sistem teknologi, kepemimpinan dan kerjasama tim.

Model kepemimpinan merupakan hal penting dalam menentukan kinerja perusahaan dalam mencapai tujuannya. Kepemimpinan dalam Islam dibangun dengan prinsip pertengahan dan moderat dalam memandang persoalan dan memberikan sauri tauladan baik bagi bawahannya. Seorang pemimpin paling tidak memiliki persyaratan yaitu kemampuan intelektual yang tinggi, analisa tajam, percaya diri, berjiwa besar, memahami orang, pioneer, inovator, visioner dan obsesi kuat kepada tujuan. Dan Rasulullah SAW sendiri merupakan sauri tauladan bagi umat Islam hal ini sesuia dengan firman Allah SWT dalam surat Al-Ahzab ayat 21.39.

Model kepemimpinan yang dimiliki kedua BPRS jelas berbeda sesuai visi dan misi perusahaan. Sedikit catatan, berdasarkan hasil kuesioner, skor terendah kepemimpinan kedua BPRS yaitu pada proses pengambilan keputusan. Konsep syura atau musyawarah dalam pengambilan keputusan, sebaiknya lebih diutamakan. Sedangkan, pola rekruitmenm, penilaian kepuasan karyawan dan penilaian motivasi kedua lembaga dirasa masih kurang. Perlu adanya evaluasi secara berkelanjutan akan ketiga hal ini agar visi, misi perusahaan tercapai dengan baik.

\section{SARAN PENELITIAN}

Berdasarkan hasil penelitain dan temuan dilapangan, ada beberapa saran yang bisa dijadikan bahan pertimbangan kedua BPRS dalam meningkatkan kinerjanya, yaitu:

1. Penilaian kinerja perusahaan dengan pendekatan BSC bisa diterapkan di kedua BPRS,

2. Pada prespektif konsumen, bank bisa lebih meningkatkan kualitas produk/ jasa agar mampu bersaing dengan lainnya, peningkatan pada market share serta pengurangan pembiayaan bermasalah,

3. Pada prespektif pempelajaran dan pertumbuhan bank lebih memperhatikan aspek kepuasan karyawan, motivasi karyawan, gaya kepemimpinan, dan kerjasama tim. Karena sumber daya manusia merupakan aset yang paling berharga dalam sebuah organisasi. 
Keterbatasan pada penelitian ini yaitu objek penelitian yang terbatas, hanya membandingkan dua BPRS dan untuk rekomendasi kedepan bisa membandingkan lembaga keuangan syariah dengan lembaga keuangan konvensional. Aspek syariah dalam penelitian ini tidak dibahas begitu dalam, hanya point penting terkait manajemen syariah yang dijelaskan. Rekomendasi bagi penelitian selanjutnya yaitu bisa membandingkan teori BSC dengan shariah compliant pada bank syariah dan penambahan objek penelitian.

\section{CATATAN AKHIR}

1 Naresh Makhijani dan Jamees Creelman, Menciptakan Balanced Scorecard untuk Organisasi Jasa Keuangan (Jakarta: Esensi, Erlangga Group, 2012), h. 2.

2 Naresh Makhijani dan Jamees Creelman, Menciptakan Balanced Scorecard untuk Organisasi Jasa Keuangan (Jakarta: Esensi, Erlangga Group, 2012), h. 7.

3 Naresh Makhijani dan Jamees Creelman, Menciptakan Balanced Scorecard untuk Organisasi Jasa Keuangan (Jakarta: Esensi, Erlangga Group, 2012), h. 12-14.

4 Naresh Makhijani dan Jamees Creelman, Menciptakan Balanced Scorecard untuk Organisasi Jasa Keuangan (Jakarta: Esensi, Erlangga Group, 2012), h. 8-9.

5 Yanne C. Tahaka, "Penerapan Balanced Scorecard Sebagai Alat Ukur Kinerja Pada PT. Bank Sulut,” Jurnal: EMBA, Vol.1 No.4 Desember (2013), Fakultas Ekonomi dan Bisnis Universitas Sam Ratulangi Manado, h. 402.

6 Lianto, "Keunggulan Balanced Scorecard Sebagai Sitem Manajemen Strategis yang Holistik", Jurnal Ekonomi, STIE Widya Dharma Pontianak, (Th. 2010), hlm. 1-2.

7 Bank Indonesia, Laporan Perekonomian Indonesia 2013 (Jakarta: Bank Indonesia, 2013), Bagian I: Tinjauan Umum, h. 1-2.

8 Halim Alamsyah, "Perkembangan dan Prospek Perbankan Syariah Indonesia: Tantangan Dalam Menyongsong MEA 2015”, Paper disampaikan dalam Ceramah Ilmiah Ikatan Ahli Ekonomi Islam (IAEI), Milad ke-8 IAEI, 13 April (2012), h. 3.

9 Mulya E. Siregar, “Outlook Perbankan Syariah 2014”, Makalah dipresentasikan dalam acara Seminar Akhir Tahun Bank Indonesia, Jakarta 16 Desember (2013), h. 5 .

10 Walikota Yogyakarta, "Peraturan Walikota Yogyakarta Nomor 38 Tahun (2013)", dalam tim, Rencana Kerja Pembangunan Daerah Kota Yogyakarta tahun 2014, (Yogyakarta: Sekertariat Daerah Yogyakarta), BAB II, h. 1.

11 Bank Indonesia, "Laporan Perkembangan Perekonomian Daerah Istimewa Yogyakarta Triwulan IV 2014”, dalam tim penulis, Laporan Perkembangan Perekonomian Daerah Istimewa Yogyakarta (Yogyakarta: Kantor Perwakilan Bank Indonesia DIY, 2014), h. 60.

12 Moh. Wahyudin Zarkasyi, Good Corporate Governance: Pada Badan Usaha Manufaktur, Perbankan, dan Jasa Keuangan Lainnya (Bandung: Alfabeta, 2008), h. 48 . 
13 Mulyadi, Akuntansi Manajemen: Konsep, Manfaat, dan Rekayasa (Jakarta: Salemba Empat, 2001), Edisi 3, h. 36.

, Balanced Scorecard: Alat Manajemen Kontemporer untuk Penglipatan Kinerja Keuangan Perusahaan (Jakarta: PT. Salemba Empat, 2001), h. 40-41.

15 Vincent Gaspersz, Sisten Manajemen Kinerja terintegrasi: BSC dengan Sis Sigma untuk Organisasi Bisnis $\mathcal{E}$ Pemerintaha (Jakarta: Gramedia Pustaka, 2003), h. 9.

16 Vincent Gaspersz, Sisten Manajemen Kinerja terintegrasi: BSC dengan Sis Sigma untuk Organisasi Bisnis $\mathcal{E}$ Pemerintaha (Jakarta: Gramedia Pustaka, 2003), h. 10.

17 Mulyadi, Balanced Scorecard: Alat Manajemen Kontemporer untuk Penglipatan Kinerja Keuangan Perusahaan (Jakarta: PT. Salemba Empat, 2001), h. 18-24.

18 Suwardi Luis \& Prima A. Biromo, Step by Step in Cascading Balanced Scorecard to Functional Scorecard (Jakarta: PT. Gramedia Pustaka Utama, 2013), h. 26.

19 Robert S. Kaplan \& Davis P. Norton, "Linking the Balanced Scorecard to Strategy”, California Management Review, Vol. 39. No.1, Fall (1996), Amerika Serikat, h. 59.

20 Robert S. Kaplan \& Davis P. Norton, "Linking the Balanced Scorecard to Strategy”, California Management Review, Vol. 39. No.1, Fall (1996), Amerika Serikat, h. 62

21 Mulyadi, Balanced Scorecard: Alat Manajemen Kontemporer untuk Penglipatan Kinerja Keuangan Perusahaan (Jakarta: PT. Salemba Empat, 2001), h. 287.

22 Ahmad Ibrahim Abu Sinn, Manajemen Syariah (Jakarta: PT. RajaGrafindo Persada, 2008), h. 235-236.

23 Kadek Yenni Widiastiti \& I Ketut Yadnyana, "Analisis Perbandingan Kinerja BPR Mitra Balijaya Mandiri \& BPR Cahaya Bina Werdhi dengan Pendekatan BSC", EJurnal Akutansi, Universitas Udaya Bali, Edisi 4.3 (tahun 2013), h. 605 621.

24 Yanne Christiani Tahana, "Penerapan BSC sebagai Penilaian Kinerja pada Bank Sulawesi Utara”, Jurnal EMBA, Vol.1. No.4 Desember (2013), h. 402-413.

24 Ari Kuntardina \& Prasto Dwi Wahjono, "Penerapan Manajemen BSC pada BPR Nusumma Cabang Blora Jawa Tengah”, Jurnal Manajemen Dan Penelitian Akuntansi, Vol. 6. No. 1. Juni (2012), h. 1-84.

26 Herlina Puji Astuti, Herry Susanta \& Apriatani EP, "Penerapan BSC pada PD. Bank Pasar Kabupaten Kudu”, Diponegoro Journal of Social EO Politic, (tahun 2012), h. 1-8.

27 Rudy Haryanto, "Environmental BSC \& Etika Bisnis Islam”, Jurnal Al-Ahkam, Vol. VI. No. 1, Juni (2011), h. 75.

28 Nik Aiman Nik Muhamad., dkk, "The Balanced Scorecard: Structure \& Potensial Use in Malaysian Islamic Bank", The $5^{\text {th }}$ International Conference on Financial Criminology, (2013), h. 161-179.

29 Sheila Nu Nu Htay \& Syed Ahmed Salman, "Balanced Scorecard Approach for Better Shariah Corporate Governance”, American Journal of Applied Sciences 10 (12): 1553-1557, (2013).

30 Mohammad Ali Shahhoseini, Sahand Khassehkhan, \& Nahid Shanyani, "Identifying Key Performance Indicators of an Iranian Islamic Bank Based on BSC 
and AHP”, Journal of American Science, (2012), h. 84-73.

31 Robert S. Kaplan \& Davis P. Norton, Translating Strategy in to Action The Balanced Scorecard", United State of America: Harvard Business School Press Boston Massachusetts, (1996), h. 96.

32 Diadaptasi dari penelitian oleh Meirdania Zudia, "Analisis Penilaian Organisasi dengan Pendekatan BSC pada Bank Jateng Semarang”, Skripsi (2010), Semarang: Univesitas Diponegoro.

33 Imam Ghozali, Aplikasi Analisis Multivariate dengan Program IBM SPSS 21 (Semarang: Badan Penerbit UNDIP, 2013), h. 55.

34 Imam Ghozali, Aplikasi Analisis Multivariate dengan Program IBM SPSS 21 (Semarang: Badan Penerbit UNDIP, 2013), h. 48.

35 Muslich, Etika Bisnis Islami (EKONISIA: Yogyakarta, 2004), h. 30.

36 Akhmad Mujahidin, "Etika Bisnis Dalam Islam”, Jurnal Hukum Islam, Vol. IV. No. 2. Desember (2005), h. 119.

37 Akhmad Mujahidin, "Etika Bisnis Dalam Islam”, Jurnal Hukum Islam, Vol. IV. No. 2. Desember (2005), h. 117.

38 Sony Yuwono, Edy, Sukarno, \& Muhammad Ichsan, Petunjuk Praktis Penyusunan Balanced Scorecard: Menuju Organisasi yang Berfokus Pada Strategi (Jakarta: PT. Gramedia Pustaka Utama, 2004), h. 39.

39 Ahmad Ibrahim Abu Sinn, Manajemen Syariah (Jakarta: PT. RajaGrafindo Persada, 2008), h. 134.

\section{DAFTAR PUSTAKA}

Aiman, Nik. Muhamad, Nik., dkk,. 2013. "The Balanced Scorecard: Structure \& Potensial Use in Malaysian Islamic Bank", The $5^{\text {th }}$ International Conference on Financial Criminology.

Alamsyah, Halim. 2012. Perkembangan dan Prospek Perbankan Syariah Indonesia: Tantangan Dalam Menyongsong MEA 2015. Disampaikan dalam Ceramah Ilmiah Ikatan Ahli Ekonomi Islam (IAEI), Milad ke-8 IAEI. 13 April 2012.

Astuti, Herlina Puji., Susanta, Herry., \& EP, Apriatani. 2012. "Penerapan BSC pada PD. Bank Pasar Kabupaten Kudu”. Diponegoro Journal of Social E Politic.

Bank Indonesia. 2013. "Laporan Perekonomian Indonesia 2013”. Jakarta: Bank Indonesia), Bagian I: Tinjauan Umum.

Bank Indonesia. 2014."Laporan Perkembangan Perekonomian Daerah Istimewa Yogyakarta Triwulan IV 2014", dalam tim penulis, Laporan Perkembangan Perekonomian Daerah Istimewa Yogyakarta. Yogyakarta: Kantor Perwakilan Bank Indonesia DIY.

Gaspersz, Vincent. 2003. Sistem Manajemen Kinerja Terintegrasi: Balanced Scorecard dengan Six Sigma Untuk Organisasi Bisnis dan Pemerintahan. Jakarta: PT. Gramedia Pustaka Utama.

Ghozali, Imam. 2013. Aplikasi Analisis Multivariate dengan Program IBM SPSS 21. Semarang: Badan Penerbit UNDIP.

Haryanto, Rudy. 2011. “Environmental BSC \& Etika Bisnis Islam”. Jurnal Al-Ahkam, 
Vol. VI. No. 1, Juni.

Htay, Sheila Nu Nu \& Salman, Syed Ahmed. 2013. "Balanced Scorecard Approach for Better Shariah Corporate Governance”, American Journal of Applied Sciences 10 (12): 1553-1557.

Kaplan, Robert S. \& Norton, Davis P. 1996. "Translating Strategy in to Action The Balanced Scorecard”. United State of America: Harvard Business School Press Boston Massachusetts.

1996. "Linking the Balanced Scorecard to Strategy". California Management Review, Vol. 39, No.1, Fall, Amerika Serikat.

Kuntardina, Ari \& Wahjono, Prasto Dwi. 2012. "Penerapan Manajemen BSC pada BPR Nusumma Cabang Blora Jawa Tengah”. Jurnal Manajemen Dan Penelitian Akuntansi, Vol. 6. No. 1, Juni.

Luis, Suwardi \& Biromo, Prima A. 2013. Step by Step in Cascading Balanced Scorecard to Functional Scorecard. Jakarta: PT. Gramedia Pustaka Utama.

Lianto. 2010. "Keunggulan Balanced Scorecard Sebagai Sitem Manajemen Strategis yang Holistik".Jurnal Ekonomi. STIE Widya Dharma Pontianak.,

Makhijani, Naresh \& Creelman, Jamees. 2012. Menciptakan Balanced Scorecard untuk Organisasi Jasa Keuangan. Jakarta: Esensi.

Mulyadi. 2001. Akuntansi Manajemen: Konsep, Manfaat, dan Rekayasa. Edisi ke-3. Jakarta: Salemba Empat.

-2001. Balanced Scorecard: Alat Manajemen Kontemporer untuk Penglipatan Kinerja Keuangan Perusahaan. Jakarta: PT. Salemba Empat.

Muslich. 2004. Etika Bisnis Islami. Yogyakarta: EKOBISIA.

Mujahidin, Akhmad. 2005. "Etika Bisnis Dalam Islam”. Hukum Islam, Vol. IV No. 2. Desember.

Shahhoseini, Mohammad Ali., Khassehkhan, Sahand., \& Shanyani, Nahid. 2012. "Identifying Key Performance Indicators of an Iranian Islamic Bank Based on BSC and AHP". Journal of American Science.

Siregar, Mulya E. 2013. Outlook Perbankan Syariah 2014. Seminar Akhir Tahun Bank Indonesia. Jakarta 16 Desember.

Sinn, Ahmad Ibrahim Abu. 2008. Manajemen Syariah. Jakarta: PT. RajaGrafindo Persada.

Tahaka, Yanne C. 2013. "Penerapan Balanced Scorecard Sebagai Alat Ukur Kinerja Pada PT. Bankk Sulut”. Jurnal: EMBA, Vol.1. No.4. Universitas Sam Ratulangi Manado: Fakultas Ekonomi dan Bisnis. Desember.

Walikota Yogyakarta. 2013.”Peraturan Walikota Yogyakarta Nomor 38 Tahun 2013". dalam tim, Rencana Kerja Pembangunan Daerah Kota Yogyakarta tahun 2014. Yogyakarta: Sekertariat Daerah Yogyakarta.

Widiastiti, Kadek Yenni \& Yadnyana, I Ketut. 2013. "Analisis Perbandingan Kinerja BPR Mitra Balijaya Mandiri \& BPR Cahaya Bina Werdhi dengan Pendekatan BSC”. E-Jurnal Akutansi. Universitas Udaya Bali. Edisi 4.3.

Yuwono, Sony., Sukarno, Edy., \& Muhammad Ichsan. 2004. Petunjuk Praktis Penyusunan Balanced Scorecard: Menuju Organisasi yang Berfokus Pada Strategi. Jakarta: PT. Gramedia Pustaka Utama. 
Zarkasyi, Moh. Wahyudin. 2008. Good Corporate Governance: Pada Badan Usaha Manufaktur, Perbankan, dan Jasa Keuangan Lainnya. Bandung: Alfabeta.

Zudia, Meirdania. 2010. "Analisis Penilaian Organisasi dengan Pendekatan BSC pada Bank Jateng Semarang”. Skripsi. Semarang: Univesitas Diponegoro. 